\title{
Rainfall and rainy day trends at Aurangabad district of Maharashtra state
}

\author{
H. P. Deshmukh* and H. H. Deshpande ${ }^{1}$ \\ Department of Soil Science, Faculty of Agriculture, Water and Land Management Institute, \\ Aurangabad (M.S.) India \\ (Email: harish.agri@ rediffmail.com; tnauharish@gmail.com)
}

\begin{abstract}
Rainfall data of 34 years (1983-2016) was obtained from agro meteorological observatory, water and land management institute (WALMI) Aurangabad and was analyzed for rainfall and rainy days trends. The trend indicates that the tract received a mean annual rainfall of $745.4 \mathrm{~mm}$ in 43 rainy days with maximum contribution (83.5\%) from south west monsoon (June to September). July was the rainiest month with $165.9 \mathrm{~mm}$ average rainfall. In last fifteen years, occurrence of slight drought and moderate drought has been increased. The annual rainfall variability during last 34 years (1983-2016) indicated that, site received 22 years normal rainfall (- 0.21 to $55.49 \%$ ), faced 6 years of slight drought $(-12.92$ to $-25.46 \%)$ and 6 years moderate drought (-33.91 to $-44.42 \%)$.
\end{abstract}

Key Words : Rainfall trend, Rainy days, Moderate drought, Normal rainfall

View Point Article : Deshmukh, H.P. and Deshpande, H.H. (2020). Rainfall and rainy day trends at Aurangabad district of Maharashtra state. Internat. J. agric. Sci., 16 (1) : 33-37, DOI:10.15740/HAS/IJAS/16.1/33-37. Copyright@ 2020: Hind Agri-Horticultural Society.

Article History : Received : 14.10.2019; Revised : 07.11.2019; Accepted : 09.12.2019

\footnotetext{
* Author for correspondence:

${ }^{1}$ Department of Agronomy, Faculty of Agriculture, Water And Land Management Institute, Aurangabad (M.S.) India

Email: deshpandewalmi@gmail.com/changadehs@gmail.com)
} 